\title{
PHAGOCYTIC AND SERUM KILLING OF CAPSULATE AND NON-CAPSULATE BACTEROIDES FRAGILIS
}

\section{J. H. ReId AND Sheila Patrick}

\section{Department of Microbiology and Immunobiology, The Queen's University of Belfast, Grosvenor Road, Belfast, BT12 6BN, Northern Ireland}

\begin{abstract}
Summary. The relative susceptibilities of capsulate and non-capsulate variants of Bacteroides fragilis to serum and phagocytic killing were investigated. The capsule of $B$. fragilis did not confer resistance to serum killing. Phagocytic killing of non-capsulate $B$. fragilis occurred at bacterial concentrations of $1 \times 10^{6}$ and $1 \times 10^{7} \mathrm{cfu} / \mathrm{ml}$. Capsulate $B$. fragilis organisms were also phagocytosed and killed at a concentration of $1 \times 10^{6} \mathrm{cfu} / \mathrm{ml}$, but phagocytosis and killing were impaired at a concentration of $1 \times 10^{7} \mathrm{cfu} / \mathrm{ml}$.
\end{abstract}

\section{INTRODUCTION}

The susceptibility of pathogenic bacteria to phagocytosis and killing by polymorphonuclear leukocytes (PMNL) and macrophages is of major importance in determining the outcome of the host-pathogen interaction. Casciato et al. (1975) and Bjornson, Altemeier and Bjornson (1976) demonstrated phagocytosis and killing of $B$. fragilis by human leukocytes in vitro. Phagocytosis of $B$. fragilis in the presence of serum occurred in aerobic and anaerobic conditions. Ingham et al. (1977 and 1981) investigated the effect of Bacteroides spp. on the phagocytic killing of facultative species. Killing of $B$. fragilis and Proteus mirabilis in mixtures in vitro was impaired when the concentration of $B$. fragilis was greater than $1 \times 10^{7} \mathrm{cfu} / \mathrm{ml}$ in the phagocytic system. Tofte et al. (1980) and Jones and Gemmel (1982) reported that both phagocytic uptake and killing of facultative species were impaired at high concentrations of bacteroides. None of these studies defined the ratio of capsulate to non-capsulate bacteroides used in the phagocytic system.

Considerable emphasis has been placed on the importance of the polysaccharide capsule of $B$. fragilis ATCC23745 as a virulence determinant (Kasper et al., 1977; Onderdonk et al., 1977). Kasper et al. (1980) reported that in-vivo passage of this strain enhanced the production of the capsule but serial subculture in vitro reduced the proportion of capsulate bacteria. Simon et al. (1982) compared phagocytosis of these strains and successfully demonstrated a reduction in uptake of the in-vivo passaged variant.

Recently, Percoll density gradient centrifugation was successfully used to separate capsulate and non-capsulate variants of B. fragilis (Patrick and Reid, 1983). In the 
present study, the susceptibilities of these variants to phagocytosis, intracellular killing and the bactericidal action of serum were investigated.

\section{MATERIALS AND METHODS}

Bacterial strains. B. fragilis NCTC9343 was supplied by the Department of Bacteriology, University of Edinburgh Medical School; $B$. fragilis ATCC23745 by the American Type Culture Collection, Rockville, MD; and B. fragilis NCTC10584 was a departmental stock culture.

Bacterial culture methods. Bacteria grown in defined broth (Van Tassell and Wilkins, 1978) were used in all experiments except where otherwise stated. Cultures were incubated at $37^{\circ} \mathrm{C}$ in an atmosphere of $\mathrm{H}_{2} 90 \%$ and $\mathrm{CO}_{2} 10 \%$ in anaerobic jars. The standard anaerobic procedures of Collee et al. (1972) were used.

Stock cultures, grown in defined broth, were snap frozen in liquid $\mathrm{N}_{2}$ and $1-\mathrm{ml}$ portions stored at $-70^{\circ} \mathrm{C}$ or in liquid $\mathrm{N}_{2}$. Capsulate bacteria, recovered from the $0-20 \%$ interface of a Percoll (Pharmacia, London) discontinuous density gradient (Patrick and Reid, 1983) and grown to late log-phase in defined broth, provided a capsulate stock which was stored as above.

Bacteria were also cultured in basal broth (Deacon, Duerden and Holbrook, 1978). Total viable counts were determined by seeding lysed human blood agar with six $20-\mu \mathrm{l}$ drops from a standard 20-gauge steel cannula (Astell, London).

Preparation of bacteria. Bacteria were grown to late log-phase in defined broth medium. A 3-ml volume of a capsulate culture preparation was layered on to a $20 \%$ Percoll cushion. After centrifugation at $2600 \mathrm{~g}$ for $20 \mathrm{~min}$ a homogeneous suspension of capsulate bacteria was recovered from the $0-20 \%$ interface, suspended in quarter strength Ringer solution (Oxoid, Basingstoke, Hampshire) and centrifuged at $10000 \mathrm{~g}$ for $30 \mathrm{~min}$ at $4^{\circ} \mathrm{C}$. Non-capsulate bacteria obtained from the $60-80 \%$ interface of a Percoll density gradient were also washed once in Ringer solution. Standard bacterial suspensions at concentrations of $1 \times 10^{7}$ or $1 \times 10^{8} \mathrm{cfu} / \mathrm{ml}$ were prepared in Hanks' balanced salt solution (HBSS) containing gelatin $0.01 \% \mathrm{w} / \mathrm{v}$ (GEL-HBSS).

Preparation of phagocytes. Ficoll isopaque gradients were used to separate leukocytes from $25 \mathrm{ml}$ of heparinised human blood. Leukocytes were washed twice in HBSS, and pure PMNL preparations were obtained by centrifugation of the leukocyte suspension on a preformed Percoll sucrose density gradient.

A stock solution of Percoll, isosmotic with physiological saline, was prepared by diluting nine volumes of Percoll in one volume of tenfold concentrated HBSS. The $p \mathrm{H}$ of this solution was adjusted to $7 \cdot 2$ with $1 \mathrm{M} \mathrm{HCl}$, and a $65 \%$ Percoll solution was then prepared by the addition of $0.25 \mathrm{~m}$ sucrose. Suitable volumes were centrifuged at $21000 \mathrm{~g}$ for $20 \mathrm{~min}$ to produce gradients. Leukocytes suspended in $1 \mathrm{ml}$ of HBSS were applied to the top of a gradient which was then centrifuged at $600 \mathrm{~g}$ for $15 \mathrm{~min}$. A sharp band of PMNL formed in the lower part of the gradient just above the band of erythrocytes; the cells were removed carefully with a Pasteur pipette, washed in HBSS and resuspended to a final concentration of $1 \times 10^{7} \mathrm{cells} / \mathrm{ml}$.

Serum. Normal human group AB serum was obtained from the Northern Ireland Blood Transfusion Service; $2-\mathrm{ml}$ volumes of sera were stored at $-20^{\circ} \mathrm{C}$. The total haemolytic complement value ( $\mathrm{CH} 50)$ was checked routinely, and only sera with normal $\mathrm{CH} 50$ values were used.

Phagocytosis. Sterile siliconised screw-capped glass tubes $(98 \times 16 \mathrm{~mm})$ containing a phagocytic system composed of $0.3 \mathrm{ml}$ of PMNL suspension, $0.3 \mathrm{ml}$ of $\mathrm{AB}$ serum, $0.3 \mathrm{ml}$ of appropriate bacterial suspension and $2 \cdot 1 \mathrm{ml}$ of GEL-HBSS were incubated at $37^{\circ} \mathrm{C}$ in aerobic conditions with end-over-end rotation. GEL-HBSS was used to bring the final volume to 3.0 $\mathrm{ml}$. Final PMNL and serum concentrations were $1 \times 10^{6}$ cells $/ \mathrm{ml}$ and $10 \%$ respectively, and final bacterial concentrations were either $1 \times 10^{7}$ or $1 \times 10^{6} \mathrm{cfu} / \mathrm{ml}$. Appropriate control mixtures were included. All experiments were performed in duplicate and repeated at least twice. Phagocytic killing at 0 and 120 min was measured by diluting $0.1 \mathrm{ml}$ of the reaction mixture into $9.9 \mathrm{ml}$ of distilled water containing bovine serum albumin $0.01 \%$. After $5 \mathrm{~min}$, further tenfold dilutions were performed in Ringer solution and total viable counts were determined. Phagocytic uptake after $0,30,60$ and 120 min was measured by diluting $0.5 \mathrm{ml}$ of 
the reaction mixture in $1.5 \mathrm{ml}$ of chilled GEL-HBSS to stop phagocytosis. The suspension was centrifuged at $110 \mathrm{~g}$ for $4 \mathrm{~min}$ at $4^{\circ} \mathrm{C}$ and the viable bacteria in the supernate were counted.

Light microscopy. Capsules were detected by light microscopy with India ink or eosin-carbol fuchsin negative staining methods (Cruickshank, Duguid and Swain, 1965).

PMNL were recovered from the phagocytic system by centrifugation at $210 \mathrm{~g}$ for $4 \mathrm{~min}$ and resuspended in HBSS containing $50 \%$ heat-inactivated normal human serum. Smears were prepared and stained by the M \& D Diff-Quick ${ }^{\circledR}$ staining set (Merz and Dade AG, Switzerland). Preparations were examined with a $\times 100$ oil immersion objective and the number of bacteria/50 PMNL counted.

Electronmicroscopy. PMNL for electronmicroscopy were recovered from the phagocytic system by centrifugation at $210 \mathrm{~g}$ for $4 \mathrm{~min}$, resuspended in $0 \cdot 1 \mathrm{M}$ Sorensen's phosphate buffer $p \mathrm{H}$ $7 \cdot 3$ (SPB) containing glutaraldehyde $2.5 \% \mathrm{v} / \mathrm{v}$ and left at $4{ }^{\circ} \mathrm{C}$ for $1 \mathrm{~h}$. Cells were washed twice in SPB, resuspended in SPB containing osmic acid $1 \% \mathrm{v} / \mathrm{v}$, left at $22^{\circ} \mathrm{C}$ for $1 \mathrm{~h}$ and then washed twice in SPB, dehydrated in graded ethyl alcohols and embedded in Spurr resin. Sections for electronmicroscopy were stained with uranyl acetate and lead citrate and viewed in a Philips 301 transmission electronmicroscope.

\section{RESULTS}

\section{Bactericidal activity of human serum}

Capsulate and non-capsulate variants of two of the three test strains (NCTC9343 and NCTC10584) showed no reduction in viable counts after incubation for $2 \mathrm{~h}$ in $10 \%$ normal human serum (table I). The non-capsulate variant of $B$. fragilis ATCC23745 was also resistant to serum killing, but the capsulate variant of this strain was susceptible to the bactericidal action of $10 \%$ normal human serum (table I). Control experiments indicated that GEL-HBSS was not toxic to capsulate $B$. fragilis ATCC23745.

\section{TABLE I}

Susceptibility of capsulate and non-capsulate variants of B. fragilis to serum and phagocytic killing

\begin{tabular}{|c|c|c|c|}
\hline \multirow[b]{2}{*}{ Organism } & \multirow{2}{*}{$\begin{array}{l}\text { Ratio of } \\
\text { bacteria } \\
\text { to PMNL }\end{array}$} & \multicolumn{2}{|c|}{ Total viable count* $(\mathrm{cfu} / \mathrm{ml})$ after } \\
\hline & & $0 \mathrm{~min}$ & $120 \mathrm{~min}$ \\
\hline B. fragilis NCTC9343 (NC) & $\begin{aligned} 10: 1 \\
1: 1 \\
\text { Serum con }\end{aligned}$ & $\begin{array}{l}1.5 \pm 0.2 \times 10^{7} \\
1.4 \pm 0.2 \times 10^{6} \\
1.3+0.1 \times 10^{6}\end{array}$ & $\begin{array}{l}3 \cdot 5 \pm 2 \cdot 8 \times 10^{6} \\
1 \cdot 0 \pm 0.1 \times 10^{5} \\
1 \cdot 5+0.2 \times 10^{6}\end{array}$ \\
\hline \multirow[t]{2}{*}{ B. fragilis NCTC9343 (C) } & $\begin{array}{c}10: 1 \\
1: 1\end{array}$ & $\begin{array}{l}1 \cdot 1 \pm 0.2 \times 10^{7} \\
1 \cdot 1 \pm 0.1 \times 10^{6}\end{array}$ & $\begin{array}{l}1 \cdot 1 \pm 0.1 \times 10^{7} \\
5 \cdot 2 \pm 0.9 \times 10^{4}\end{array}$ \\
\hline & Serum control & $1 \cdot 2 \pm 0.1 \times 10^{6}$ & $1 \cdot 0 \pm 0.1 \times 10^{6}$ \\
\hline \multirow[t]{2}{*}{ B. fragilis NCTC10584 (NC) } & $10: 1$ & $1.7 \pm 0.2 \times 10^{7}$ & $4.6 \pm 0.9 \times 10^{6}$ \\
\hline & $\begin{array}{c}1: 1 \\
\text { Serum control }\end{array}$ & $\begin{array}{l}2.1 \pm 0.1 \times 10^{6} \\
1.9+0.1 \times 10^{6}\end{array}$ & $\begin{array}{l}0.9 \pm 0.1 \times 10^{5} \\
2 \cdot 1 \pm 0.2 \times 10^{6}\end{array}$ \\
\hline \multirow[t]{2}{*}{ B. fragilis $\mathrm{NCTC} 10584(\mathrm{C})$} & $10: 1$ & $\begin{array}{l}1.9 \pm 0.2 \times 10^{7} \\
1.9+0.1 \times 10^{6}\end{array}$ & $\begin{array}{l}1.8 \pm 0.3 \times 10^{7} \\
5.5+0.3 \times 10^{5}\end{array}$ \\
\hline & Serum control & $1.8 \pm 0.1 \times 10^{6}$ & $\begin{array}{l}5.5 \pm 0.3 \times 10 \\
1.9 \pm 0.2 \times 10^{6}\end{array}$ \\
\hline \multirow[t]{2}{*}{ B. fragilis ATCC23745 (NC) } & $10: 1$ & $2.9 \pm 0.3 \times 10^{7}$ & $3.0 \pm 0.2 \times 10^{6}$ \\
\hline & $\begin{array}{l}1: 1 \\
\text { Serum control }\end{array}$ & $\begin{array}{l}2 \cdot 2 \pm 0.4 \times 10^{6} \\
2 \cdot 3+0.2 \times 10^{6}\end{array}$ & $\begin{array}{l}3.5 \pm 1.0 \times 10^{4} \\
2.5+0.2 \times 10^{6}\end{array}$ \\
\hline \multirow[t]{2}{*}{ B. fragilis ATCC23745 (C) } & $10: 1$ & $0 \cdot 7 \pm 0 \cdot 1 \times 10^{7}$ & $1.0 \pm 0.9 \times 10^{5}$ \\
\hline & $\begin{array}{c}1: 1 \\
\text { Serum control }\end{array}$ & $\begin{array}{l}1 \cdot 2 \pm 0 \cdot 1 \times 10^{6} \\
1 \cdot 1 \pm 0.1 \times 10^{6}\end{array}$ & $\begin{array}{l}1 \cdot 5 \pm 0.4 \times 10^{4} \\
2 \cdot 2 \pm 0.5 \times 10^{4}\end{array}$ \\
\hline
\end{tabular}

$\mathrm{PMNL}=$ polymorphonuclear leukocyte; $\mathrm{C}=$ capsulate $\mathrm{NC}=$ non-capsulate.

$*=$ mean $\pm \mathrm{SE}$. 


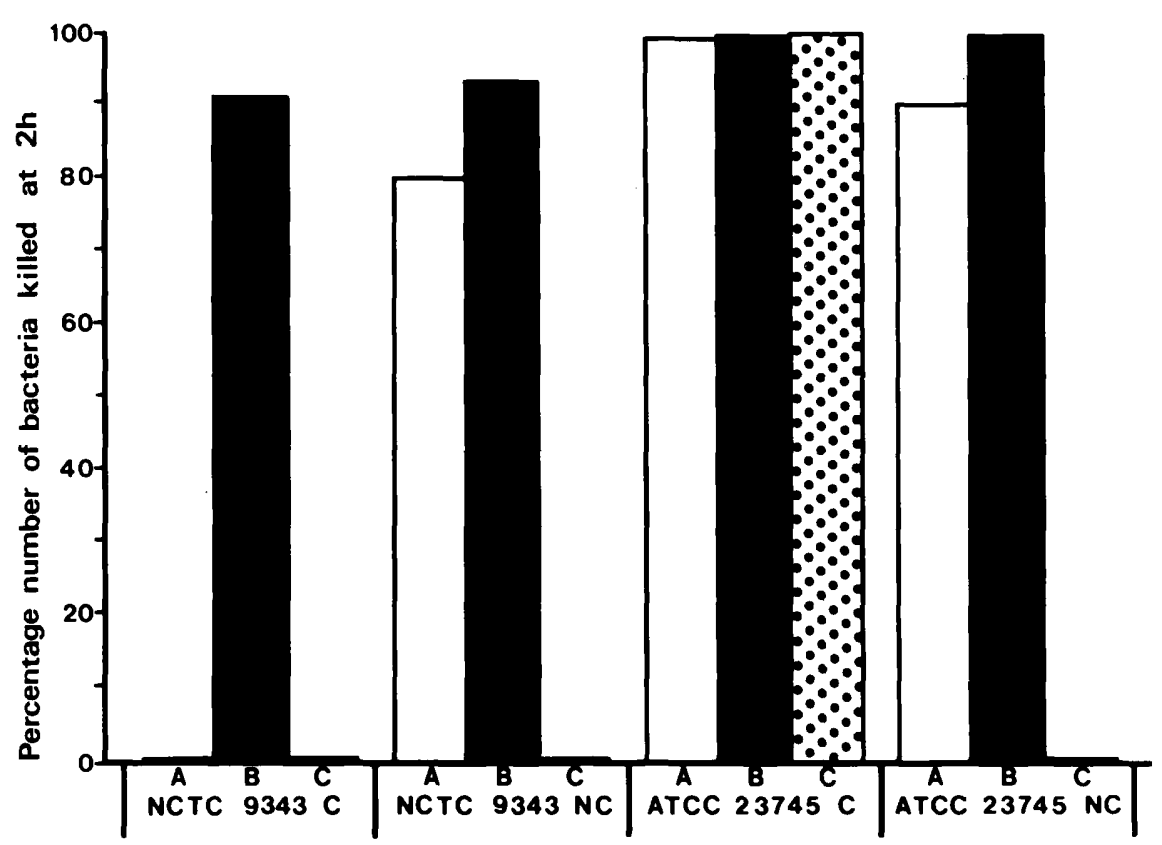

FiG. 1.-A comparison of killing of capsulate (C) and non-capsulate (NC) variants of $B$. fragilis NCTC9343 and ATCC 23745 by PMNL and serum. A-bacteria to PMNL ratio=10:1; B-bacteria to PMNL ratio $=1: 1 ; \mathrm{C}$-bacteria without $\mathrm{PMNL}$; all mixtures contained serum.

\section{Killing by polymorphonuclear leukocytes}

The results in table I and fig. 1 indicate that phagocytic killing of the three non-capsulate strains of $B$. fragilis grown in defined broth occurred at bacterial concentrations of $1 \times 10^{6}$ and $1 \times 10^{7} \mathrm{cfu} / \mathrm{ml}$ (i.e., bacteria to PMNL ratios of $1: 1$ and 10:1 respectively). Non-capsulate $B$. fragilis NCTC9343 grown in basal broth was also susceptible to phagocytic killing at both bacterial concentrations (table II).

The capsulate variants of $B$. fragilis NCTC 9343 and NCTC10584 were killed by

\section{TABLE II}

Susceptibility of capsulate and non-capsulate variants of B. fragilis NCTC9343 grown in basal broth to phagocytic killing by PMNL

\begin{tabular}{|c|c|c|c|c|}
\hline \multirow{2}{*}{$\begin{array}{l}\text { State of test } \\
\text { organism }\end{array}$} & \multirow{2}{*}{$\begin{array}{c}\text { Ratio of } \\
\text { bacteria } \\
\text { to PMNL }\end{array}$} & \multicolumn{2}{|c|}{ Total viable count* $(\mathrm{cfu} / \mathrm{ml})$ after } & \multirow{2}{*}{$\begin{array}{c}\text { Percentage } \\
\text { number of } \\
\text { bacteria } \\
\text { killed }\end{array}$} \\
\hline & & $0 \mathrm{~min}$ & $120 \mathrm{~min}$ & \\
\hline Capsulate & $\left\{\begin{array}{c}10: 1 \\
1: 1 \\
\text { Serum control }\end{array}\right.$ & $\begin{array}{l}3 \cdot 2 \pm 0 \cdot 2 \times 10^{7} \\
6 \cdot 1 \pm 0 \cdot 4 \times 10^{6} \\
6 \cdot 7 \pm 0 \cdot 7 \times 10^{6}\end{array}$ & $\begin{array}{l}9 \cdot 1 \pm 0.5 \times 10^{6} \\
3.6 \pm 0.2 \times 10^{5} \\
7 \cdot 0 \pm 0.5 \times 10^{6}\end{array}$ & $\begin{array}{r}72 \\
92 \\
0\end{array}$ \\
\hline Non-capsulate & $\left\{\begin{array}{c}10: 1 \\
1: 1 \\
\text { Serum control }\end{array}\right.$ & $\begin{array}{l}2 \cdot 9 \pm 0 \cdot 1 \times 10^{7} \\
8 \cdot 5 \pm 0.5 \times 10^{6} \\
6 \cdot 7 \pm 0.2 \times 10^{6}\end{array}$ & $\begin{array}{l}7 \cdot 4 \pm 0.3 \times 10^{6} \\
5 \cdot 2 \pm 0.4 \times 10^{5} \\
6 \cdot 6 \pm 0.3 \times 10^{6}\end{array}$ & $\begin{array}{r}75 \\
94 \\
0\end{array}$ \\
\hline
\end{tabular}

PMNL = Polymorphonuclear leukocyte.

$*=$ Mean \pm SE. 
PMNL at bacterial concentrations of $1 \times 10^{6} \mathrm{cfu} / \mathrm{ml}$. However, when the bacterial concentration was increased to $1 \times 10^{7} \mathrm{cfu} / \mathrm{ml}$, phagocytic killing of these strains was inhibited (table I and fig. 1). A high proportion $(>70 \%$ ) of capsulate $B$. fragilis NCTC9343 grown in basal broth was susceptible to phagocytic killing at both bacterial concentrations (table II). Killing of capsulate B. fragilis ATCC23745 occurred at both bacterial concentrations; however, this strain was sensitive to the bactericidal action of normal human serum (table 1 and fig. 1).

\section{Phagocytosis and killing by polymorphonuclear leukocytes}

The rates of phagocytosis and killing of capsulate and non-capsulate variants of $B$. fragilis NCTC9343 were compared. At bacterial concentrations of $1 \times 10^{7} \mathrm{cfu} / \mathrm{ml}$, effective phagocytosis and killing of non-capsulate B. fragilis NCTC9343 was evident

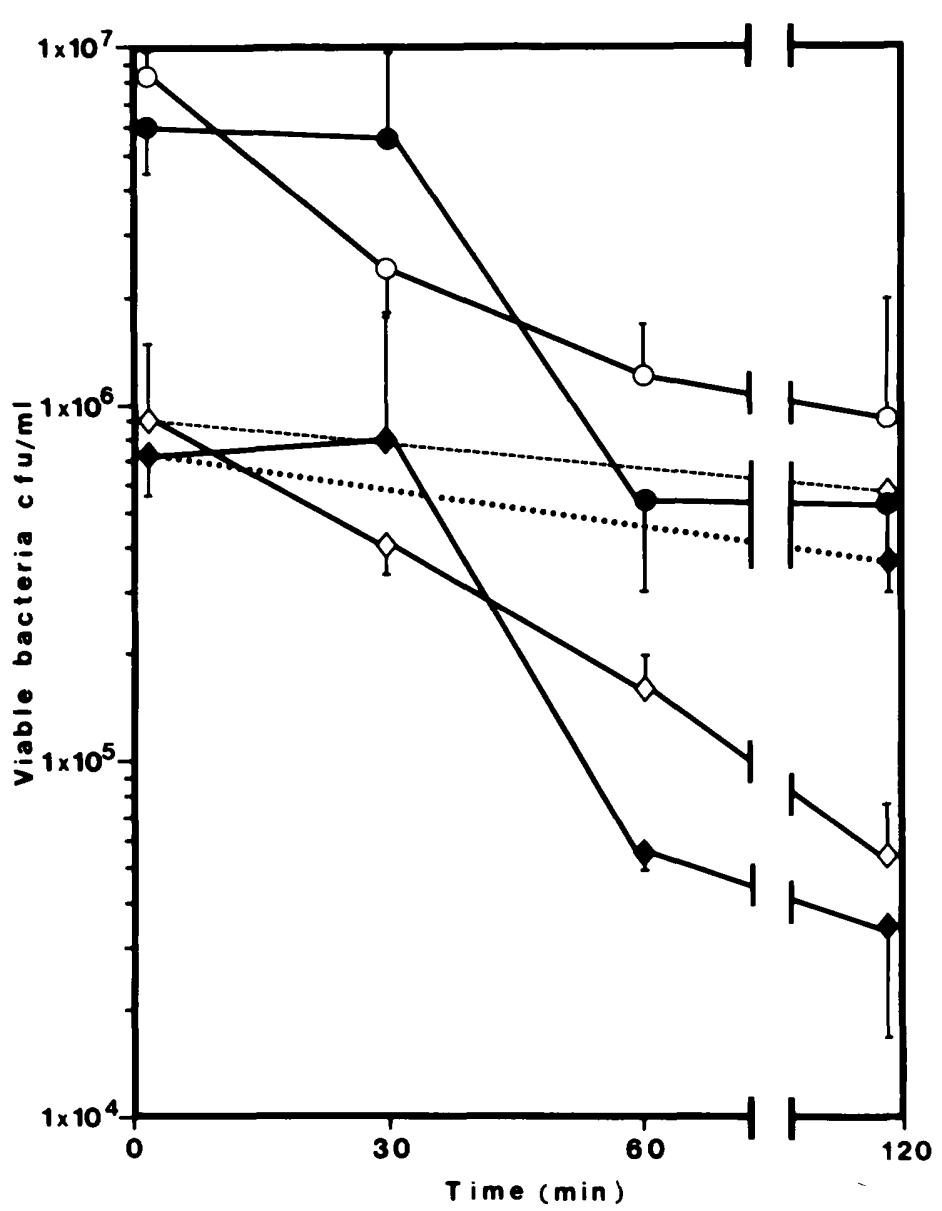

FIG. 2.-Phagocytosis and killing of non-capsulate $B$. fragilis NCTC9343 during incubation with $10 \%$ serum and PMNL. Phagocytic uptake (๑) and killing $(0)$ at a bacterial concentration of $1 \times 10^{7} \mathrm{cfu} / \mathrm{ml}$; phagocytic uptake ( $(\bullet)$ and killing ( $(0)$ at a bacterial concentration of $1 \times 10^{6} \mathrm{cfu} / \mathrm{ml}$. Controls for uptake (...) and killing (-- -) were bacteria incubated in serum without PMNL. Results from experiments performed on 3 days were combined and expressed as mean $\pm \mathrm{SE}$. 
after incubation for $60 \mathrm{~min}$ (fig. 2). However, phagocytosis of capsulate $B$. fragilis NCTC9343 was impaired after incubation for $60 \mathrm{~min}$ and no killing occurred (fig. 3). At bacterial concentrations of $1 \times 10^{6} \mathrm{cfu} / \mathrm{ml}$, phagocytosis and killing were similar with each variant (figs 2 and 3 ).

\section{Microscopy}

Phagocyte-associated bacteria were difficult to detect at a low bacteria to PMNL ratio $(1: 1)$ by light microscopy with differential staining. Smears prepared from the phagocytic system containing non-capsulate $B$. fragilis NCTC9343 at a high bacteria to PMNL ratio $(10: 1)$ showed numerous PMNL-associated bacteria. When $B$. fragilis NCTC9343 was grown in defined broth the mean number of non-capsulate bacteria per PMNL was 11; growth in basal broth increased the number of

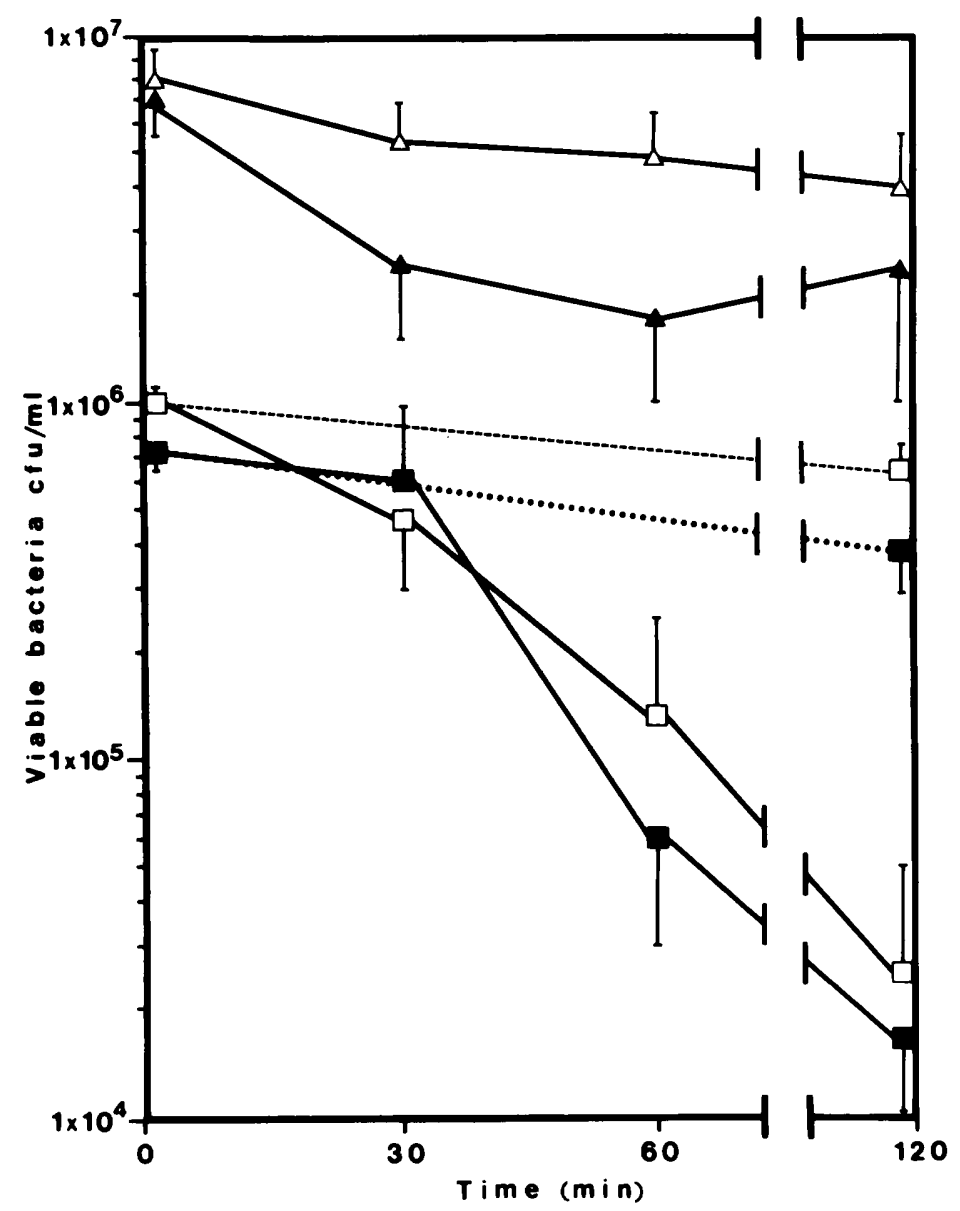

FIG. 3.-Phagocytosis and killing of capsulate $B$. fragilis NCTC 9343 during incubation with $10 \%$ serum and PMNL. Phagocytic uptake $(\Delta)$ and killing $(\Delta)$ at a bacterial concentration of $1 \times 10^{7} \mathrm{cfu} / \mathrm{ml}$;

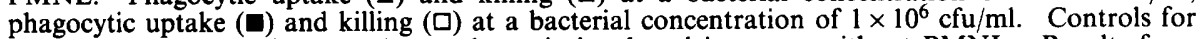
uptake (...) and killing (-..-) were bacteria incubated in serum without PMNL. Results from experiments performed on 3 days were combined and expressed as mean $\pm \mathrm{SE}$. 


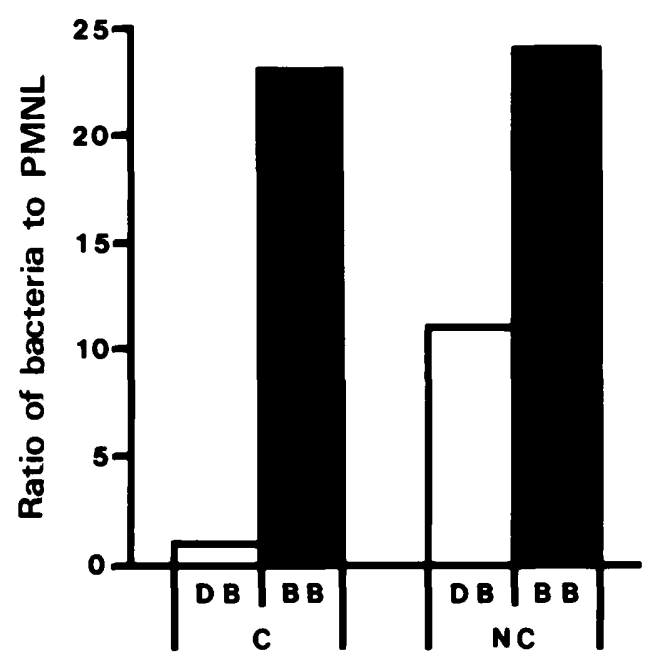

FIG. 4.-B. fragilis NCTC 9343 associated with PMNL after incubation for $60 \mathrm{~min}$ in $10 \%$ serum at $37^{\circ} \mathrm{C}$. $\mathrm{DB}=$ defined broth; $\mathrm{BB}=$ basal broth; $\mathrm{C}=$ capsulate; $\mathrm{NC}=$ non-capsulate.

phagocyte-associated bacteria to 24 (fig. 4). Electronmicroscopy confirmed the intracellular location of these organisms and demonstrated that bacteria were surrounded by phagosomal membranes (fig. 5A).

Few PMNL-associated capsulate $B$. fragilis NCTC9343 were observed at a bacteria to PMNL ratio of 10:1 (figs 4 and 5B). Electronmicroscopy revealed that some capsulate organisms were associated with the outside of the PMNL membrane (fig. 6). However, high numbers of capsulate B. fragilis NCTC9343 grown in basal broth were observed within phagocytes at a bacteria to PMNL ratio of 10:1 (fig. 4).

\section{DisCUSSION}

These findings indicate that the capsule of $B$. fragilis is not responsible for conferring resistance to serum killing.

Non-capsulate $B$. fragilis ATCC23745 grown in defined broth was resistant to serum killing, but the capsulate variant of this strain was susceptible to the bactericidal action of $10 \%$ normal human serum. The phagocytic system used in our study contained $10 \%$ normal human serum and viable counting methods were used to detect phagocytosis and killing. Phagocytosis of serum-sensitive strains could not be investigated because phagocytic killing could not be distinguished from serum killing.

Optimum phagocytic killing of both capsulate and non-capsulate $B$. fragilis occurred at bacterial concentrations of $1 \times 10^{6} \mathrm{cfu} / \mathrm{ml}$, but differences in the susceptibility to phagocytic killing were observed at bacterial concentrations of $1 \times 10^{7}$ $\mathrm{cfu} / \mathrm{ml}$. The results of our uptake and electronmicroscopy experiments suggest that ingestion of capsulate $B$. fragilis was impaired at bacterial concentrations of $1 \times 10^{7}$ $\mathrm{cfu} / \mathrm{ml}$. The surface of a particle must be completely coated with opsonin for successful phagocytosis (Griffin et al., 1975). Incomplete opsonisation of capsulate $B$. fragilis at high bacterial concentrations with limited amounts of an essential opsonin (e.g., IgM) could result in the impaired phagocytosis observed in our experiments. 

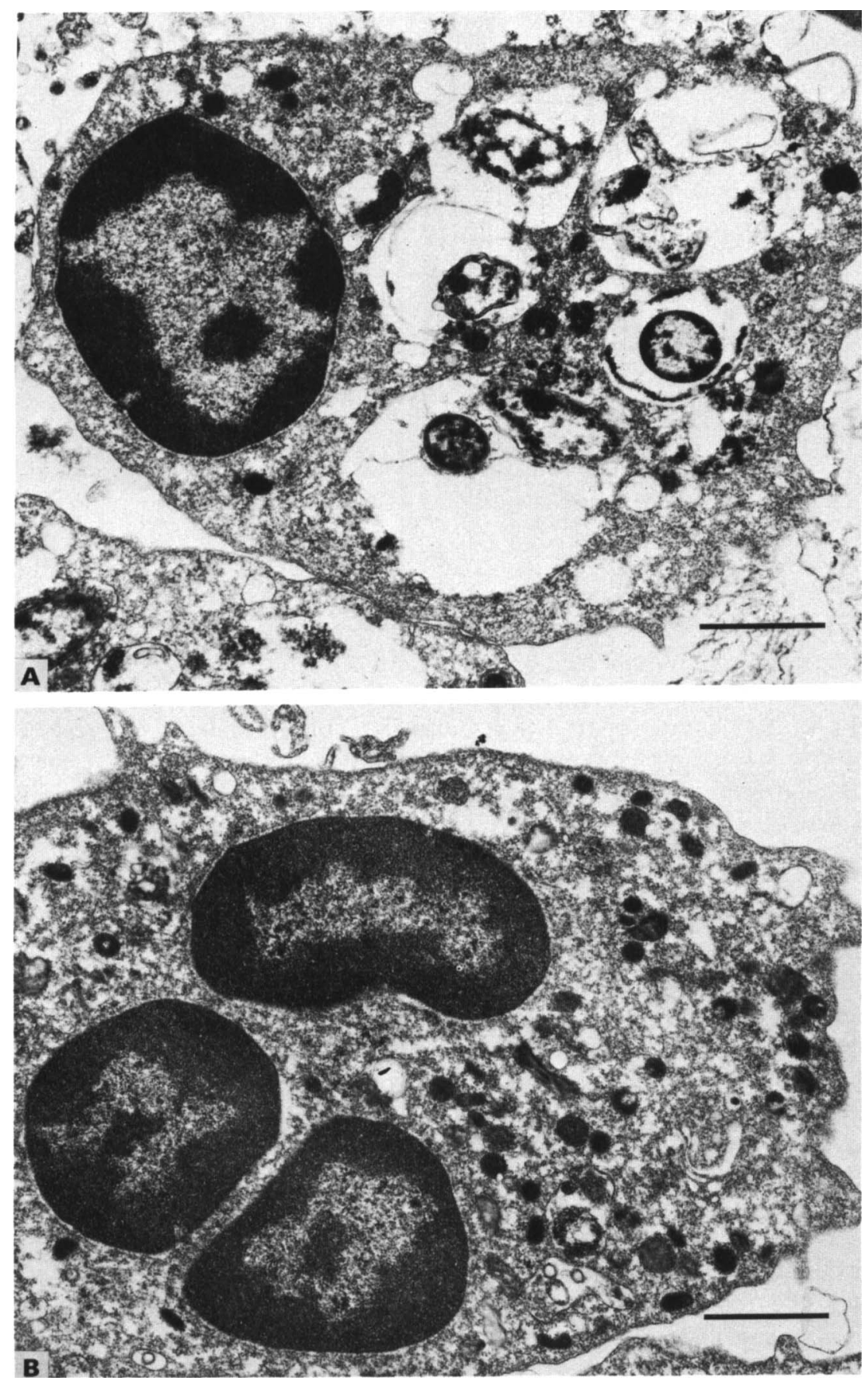

FIG. 5.-Electronmicrographs of PMNL after incubation for $60 \mathrm{~min}$ with (A) non-capsulate and (B) capsulate $B$. fragilis NCTC 9343 in the presence of $10 \%$ serum. Scale bar $=1 \mu \mathrm{m}$. 


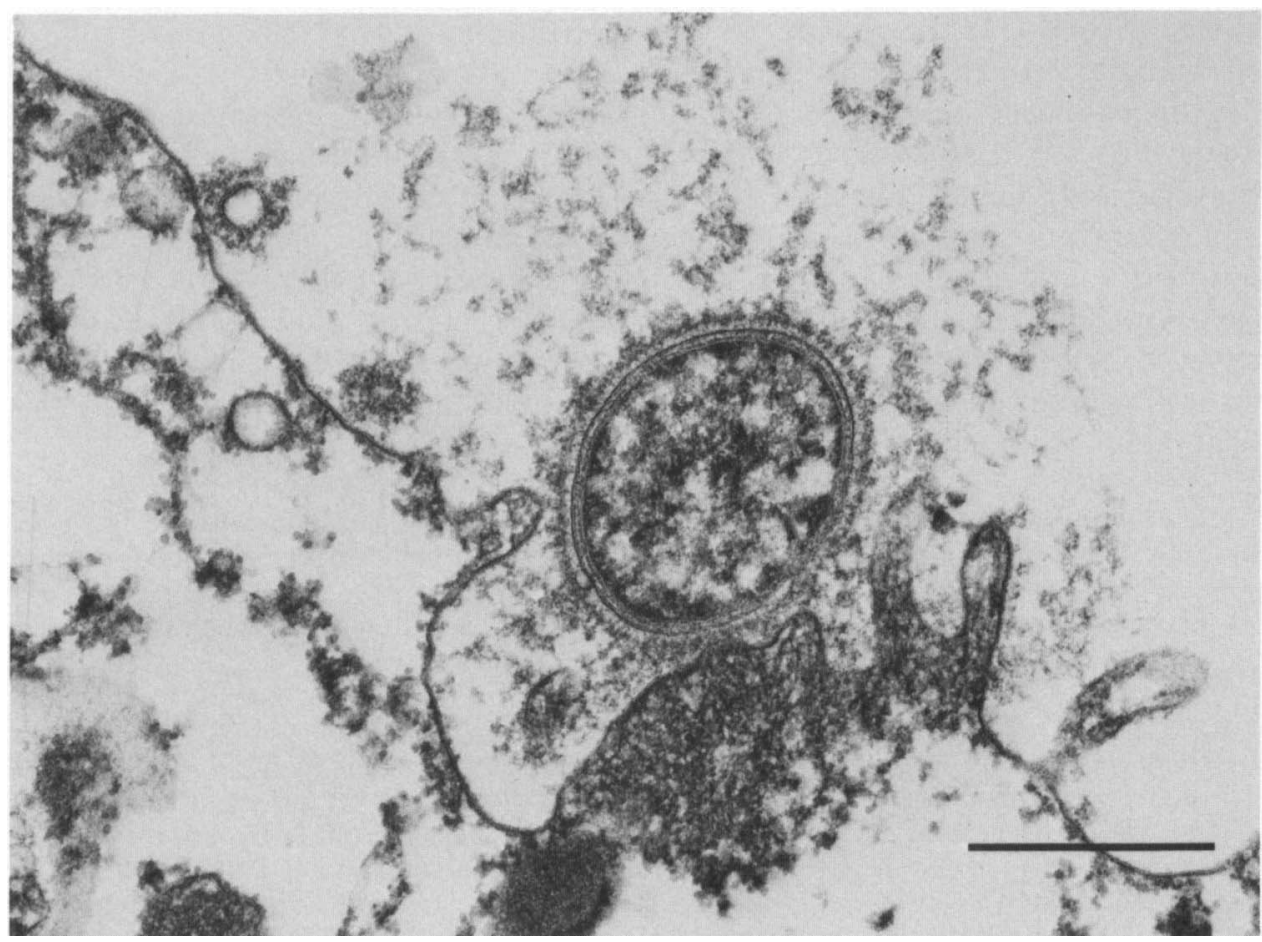

FIG. 6.-Electronmicrograph of capsulate B. fragilis NCTC9343 associated with the membrane of a PMNL after incubation for $60 \mathrm{~min}$ in the presence of $10 \%$ serum. Scale bar $=0.5 \mu \mathrm{m}$.

The capsulate variant of $B$. fragilis NCTC9343 grown in basal broth produced small capsules and was successfully phagocytosed at bacterial concentrations of $1 \times 10^{6}$ and $1 \times 10^{7} \mathrm{cfu} / \mathrm{ml}$; this suggests that the quantity of capsular material is important in impairing phagocytosis. A reduction in the quantity of opsonin required to completely cover the surface of organisms grown in basal broth could account for this observation.

Our results suggest that capsulate and non-capsulate $B$. fragilis have different opsonic requirements; this might explain the difference between our results and those obtained by other workers. Bjornson and Bjornson (1978) and Bjornson, Bjornson and Kitko (1980) demonstrated that the alternative complement pathway and IgM were essential for phagocytosis; however, Tofte et al. (1980) detected opsonisation at a reduced rate in the absence of the classical complement pathway and antibody. The proportions of capsulate and non-capsulate bacteria used in their studies were not defined. The inconsistency in these results might be explained if phagocytosis experiments were repeated with homogeneous suspensions of capsulate and non-capsulate $B$. fragilis.

Ingham et al. (1977 and 1981) observed that phagocytic killing was impaired when $P$. mirabilis and high concentrations of $B$. fragilis $\left(1 \times 10^{7} \mathrm{cfu} / \mathrm{ml}\right)$ were mixed with serum and PMNL in vitro. B. fragilis cells with large capsules might be responsible for the inhibitory effect. Horwitz and Silverstein (1980) reported that anti-capsular antibody and complement were essential for opsonisation and phagocytosis of capsulate Escherichia coli. Opsonisation of capsulate $B$. fragilis might proceed in a 
similar manner. In the phagocytic system of Ingham et al. (1977), the quantity of specific anti-capsular antibody may be insufficient to completely opsonise capsulate $B$. fragilis at a concentration of $1 \times 10^{7} \mathrm{cfu} / \mathrm{ml}$ because normal human serum contains low levels of bacteroides-specific antibodies (Hofstad, 1979). If these partially opsonised capsulate cells induced premature degranulation of PMNL lysosomes as a result of attachment to the PMNL membrane in the absence of phagocytosis, and if opsonisation of $P$. mirabilis by the alternative complement pathway proceeded at a slower rate (Tofte et al., 1980), the bactericidal mechanisms of the PMNL would be depleted before phagocytosis of $P$. mirabilis occurred. This could explain the protection from phagocytic killing. Further studies are needed to investigate this hypothesis.

The authors dedicate this paper to the memory of Professor R.R. Gillies who was Professor of Clinical Bacteriology at the Queen's University of Belfast from 1976 until his sudden death in 1983.

The authors thank Mr Alan Coffey MLSO and Mr Martin Clulow for technical assistance.

\section{REFERENCES}

Bjornson A B, Altemeier W A, Bjornson H S 1976 Comparison of the in vitro bactericidal activity of human serum and leukocytes against Bacteroides fragilis and Fusobacterium mortiferum in aerobic and anaerobic environments. Infection and Immunity 14:843-847.

Bjornson A B, Bjornson H S 1978 Participation of immunoglobulin and the alternative complement pathway in opsonization of Bacteroides fragilis and Bacteroides thetaiotaomicron. Journal of Infectious Diseases 138:351-358.

Bjornson A B, Bjornson H S, Kitko B P 1980 Participation of normal human immunoglobulins M, G and A in opsonophagocytosis and intracellular killing of Bacteroides fragilis and Bacteroides thetaiotaomicron by human polymorphonuclear leukocytes. Infection and Immunity 28:633-637.

Casciato D A, Rosenblatt J E, Goldberg L S, Bluestone R 1975 In vitro interaction of Bacteroides fragilis with polymorphonuclear leukocytes and serum factors. Infection and Immunity 11:337-342.

Collee J G, Watt B, Fowler E B, Brown R 1972 An evaluation of the Gaspak system in the culture of anaerobic bacteria. Journal of Applied Bacteriology 35:71-82.

Cruickshank R, Duguid J P, Swain R H A (eds), 1965 Medical Microbiology: a guide to the laboratory diagnosis and control of infection. 11 th ed., E \& S Livingstone Ltd, Edinburgh. pp 657-660.

Deacon A G, Duerden B I, Holbrook W P, 1978 Gas-liquid chromatographic analysis of metabolic products in the identification of Bacteroidaceae of clinical interest. Journal of Medical Microbiology 11:81-99.

Griffin Jr F M, Griffin J A, Leider J E, Silverstein S C 1975 Studies on the mechanism of phagocytosis. 1. Requirements for circumferential attachment of particle-bound ligands to specific receptors on the macrophage plasma membrane. Journal of Experimental Medicine 142:1263-1282.

Hofstad T 1979 Serological responses to antigens of Bacteroidaceae. Microbiological Reviews 43:103-115.

Horwitz M A, Silverstein S C, 1980 Influence of the Escherichia coli capsule on complement fixation and on phagocytosis and killing by human phagocytes. Journal of Clinical Investigation 65:82-94.

Ingham H R, Sisson P R, Middleton R L, Narang H K, Codd A A, Selkon J B 1981 Phagocytosis and killing of bacteria in aerobic and anaerobic conditions. Journal of Medical Microbiology 14:391-399.

Ingham H R, Sisson P R, Tharagonnet D, Selkon J B, Codd A A 1977 Inhibition of phagocytosis in vitro by obligate anaerobes. Lancet 2:1252-1254. 
Jones G R, Gemmell C G 1982 Impairment by Bacteroides species of opsonisation and phagocytosis of enterobacteria. Journal of Medical Microbiology 15:351-361.

Kasper D L, Hayes M E, Reinap B G, Craft F O, Onderdonk A B, Polk B F 1977 Isolation and identification of encapsulated strains of Bacteroides fragilis. Journal of Infectious Diseases 136:75-81.

Kasper D L, Onderdonk A B, Reinap B G, Lindberg A A 1980 Variations of Bacteroides fragilis with in vitro passage: presence of an outer membrane-associated glycan and loss of capsular antigen. Journal of Infectious Diseases 142:750-756.

Onderdonk A B, Kasper D L, Cisneros R L, Bartlett J G 1977 The capsular polysaccharide of Bacteroides fragilis as a virulence factor: comparison of the pathogenic potential of encapsulated and unencapsulated strains. Journal of Infectious Diseases 136:82-89.

Patrick S, Reid J H 1983 Separation of capsulate and non-capsulate Bacteroides fragilis on a discontinuous density gradient. Journal of Medical Microbiology 16:239-241.

Simon G L, Klempner M S, Kasper D L, Gorbach S L 1982 Alterations in opsonophagocytic killing by neutrophils of Bacteroides fragilis associated with animal and laboratory passage: effect of capsular polysaccharide. Journal of Infectious Diseases 145:72-77.

Tofte R W, Peterson P K, Schmeling D, Bracke J, Kim Y, Quie P G 1980 Opsonization of four Bacteroides species: role of the classical complement pathway and immunoglobulin. Infection and Immunity 27:784-792.

Van Tassell R L, Wilkins T D 1978 Isolation of auxotrophs of Bacteroides fragilis. Canadian Journal of Microbiology 24:1619-1621. 